DOI https://doi.org/10.18551/rjoas.2021-01.15

\title{
PROFITABILITY ANALYSIS OF FISH SELLING IN ISOKO SOUTH LOCAL GOVERNMENT AREA, DELTA STATE NIGERIA
}

\author{
Emaziye P.O.*, Ovharhe O.J. \\ Department of Agricultural Economics and Extension, Faculty of Agriculture, \\ Delta State University, Delta State, Nigeria \\ ${ }^{\star}$ E-mail: peteremaziye63@gmail.com \\ ORCID: 0000000173682186
}

\begin{abstract}
The study concentrated on the profitability of the fish selling business as its main objective. Multi-stage sampling procedure where used in purposive selection of 40 fish sellers in the study area. Data were collected with aid of structured questionnaire administered to fish sellers. Data obtained were analyzed using cost and return model and descriptive statistics such as mode mean, frequency and percentages. Young persons who were mostly married engaged in fish selling business. Fish selling business were mostly for women that took the business as a full-time and marketing experience of years 6 months. Both buying and selling price fluctuates revealing low standard price system. The revenue derived and cost incurred was $\$ 273,600$ and $\$ 211,345$ respectively. The gross margin and net return was $\$ 84,280$ and $\$ 62,255$ respectively indicating that there was profit in fish selling business. The benefits cost ratio of 1.30 revealing that for every $100 \mathrm{k}$ invested in the business $30 \mathrm{k}$ was realized also indicated profit. In brief fish selling business is profit oriented from the study. The study recommends that Government should have a uniform standard price, fixed and monitored by marketing boards. It also recommends that marketing training program should be carried out by NGOs and government for acquisition of marketing skills.
\end{abstract}

\section{KEY WORDS}

Analysis, fish, profitability, selling.

Fish are been found in vast flood-plains, inland waters network, natural lakes, reservoirs and man-made lakes (21). Nigeria expenditure on 1.9 tonnes fish importation is approximately 125.38 billion annually to meet consumption demand (8). This 1.9 tonnes of fish importation resulting to $\$ 700$ million foreign exchange annually.

Consumers of fish in Nigeria stance at $55 \%$ of total protein intake sources (1). Also findings of (15) stated that the cheapest ranked protein source is fish. (6) also collaborated that the contribution of fishing per capita animal intake is about $5 \%$ and about 8 million people engaged in fishing industry. (5) reported that good source of protein a mineral is fish which provide about $50 \%$ of mineral and protein for Africa and south Asian. The fisheries industries enhance people's incomes, livelihood, nutrition and families health and act as social change and economic development (4).

Fish protein nutrients and vitamins assist in control of heart related diseases such stroke and heart failure, moreso, help in lowering of high blood pressure, hence fish is recommended by American Heart Association to be taken minimum two times weekly (23).

Acceptable standard of profitability analysis includes the determination of cost and benefit of returns overtime adopting appropriate standard (12 and 3) in this findings asserted that the gross finding is a proof for marketing efficiency. (16) reported that marketing efficiency is usually adopted in marketing process for evaluation and performance.

In Nigeria, particularly in Delta State, the fish business is of greater advantage to production sector, with little or no knowledge in fish marketing (18). Thus, this study is focused on the behaviour of fish marketers towards profitability.

The specific objectives of this study were to:

- Examine the social economic characteristics of fish sellers;

- Examine the fish sellers business status; 
- Determine the fish seller marketing experience;

- Determine a fish seller revenue;

- Determine the fish seller total cost of marketing;

- Analyze the profitability of fish selling.

\section{CONCEPTUAL FRAMEWORK}

The conceptual framework for profitability analysis of fish selling is crucial to factors linking revenue generation in agricultural productivity. (20) poised that productivity in agricultural business in attained by the conceptual design of framework analysis. In the analysis of the profitability of fish selling, various factors taken into consideration include: social economic characteristics fish sellers, business status of the fish farmer, marketing potentials and cost variation leading to revenue generation on the accounts of positive fish business. This is a pro-profitability business cycle as shown in Figure 1.

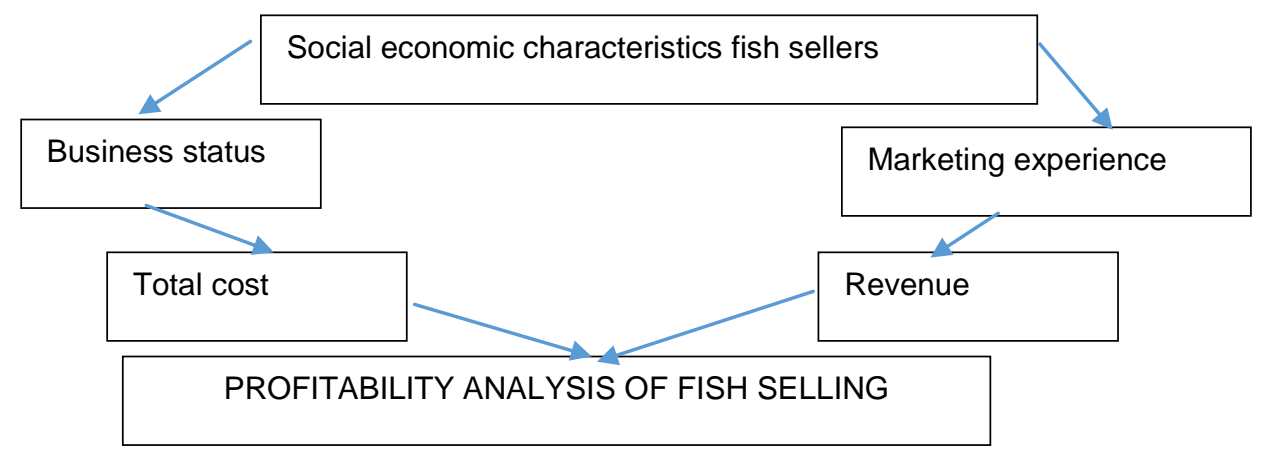

Figure 1 - Conceptual framework for the profitability analysis of fish selling

\section{METHODS OF RESEARCH}

The area is made up of 10 dans and 59 communities with its headquarters at Oleh. It has an average population of about 227,712 and lies at latitude $5.2 \mathrm{~N}$ and longitude $6.1 \mathrm{E}$ respectively. The area experiences two climatic season namely wet and dry seasons with perennial flooding mostly from many tributaries in the area that derived the source from the river Niger. The main occupation is agriculture especially fishing and crop farming.

Multistage sampling procedure where used in purposive selection of four dans that have a large fish market from the 10 dans in the area. Secondly one market each were purposive selected giving a total of 4 markets and lastly, 10 fish sellers were randomly selected giving a total of respondent to be 40 .

Data were collected with the aid of structured questionnaire administered to fishseller's. Data obtained were analyzed using benefit cost ratio model and descriptive statistics such as mean, mode, frequency and percentages.

$$
\begin{aligned}
& \mathrm{TC}_{\mathrm{fs}}=\mathrm{TV}_{\mathrm{fs}}+\mathrm{TFC}_{\mathrm{fs}} \ldots \ldots \ldots \ldots \text {.(i) } \\
& \mathrm{GM}_{\mathrm{fs}}=\mathrm{R}_{\mathrm{fs}}-\mathrm{TVC}_{\mathrm{fs}} \ldots \ldots \ldots . \text { (ii) } \\
& \mathrm{BCR}_{\mathrm{fs}}=\mathrm{TR}_{\mathrm{fs}} / \mathrm{TVC}_{\mathrm{fs}} \ldots \ldots \ldots \ldots \text { (iii) } \\
& \mathrm{NR}_{\mathrm{fs}}=\mathrm{GM}_{\mathrm{fs}}-\mathrm{THC}_{\mathrm{fs}} \ldots \ldots \ldots \text { (iv) }
\end{aligned}
$$

Where: $\mathrm{GM}_{\mathrm{fs}}=$ Gross margin of fish seller; $\mathrm{R}_{\mathrm{fs}}=$ Revenue of fish sellers; $\mathrm{TVC}_{\mathrm{fs}}=$ Total variable cost of fish sellers; $\mathrm{BCR}_{\mathrm{fs}}=$ Benefit cost ratio of fish sellers; $\mathrm{TC}_{\mathrm{fs}}=$ Total cost of fish seller; $\mathrm{TFC}_{\mathrm{fs}}=$ Total fixed cost of fish sellers.

\section{RESULTS AND DISCUSSION}

Fish sellers socio-economic characteristics respondents with age bracket of 40 51 years and 64 - 75 years were and $10.0 \%$ respectively with a mean age of 48 years. This 
clearly shown fish marketing were mostly carried out by young and energetic persons since it involves traveling and energy in carrying out marketing operations (19). Female gender participated most with a percentage of $72.5 \%$ compared to their male counterparts of $27.5 \%$ most respondents were married which educational level of secondary school and household size of 10 persons as shown in Table 1. This is in line with the report of (17) that the most household were married with family size of 8-10 persons.

Table 1 - Fish Sellers Socio-Economic Characteristics

\begin{tabular}{|c|c|c|c|}
\hline Parameters & Frequency & Percentage & Mean/Mode \\
\hline \multicolumn{4}{|l|}{ Age (years) } \\
\hline $28-39$ & 7 & 17.5 & \multirow{4}{*}{48 years } \\
\hline $40-51$ & 21 & 52.5 & \\
\hline $52-63$ & 8 & 20.0 & \\
\hline $64-75$ & 4 & 10.0 & \\
\hline \multicolumn{4}{|l|}{ Gender } \\
\hline Male & 11 & 27.5 & \multirow{3}{*}{ Female } \\
\hline Female & 29 & 72.5 & \\
\hline \multicolumn{3}{|l|}{ Marital level } & \\
\hline Married & 28 & 70.0 & \multirow[t]{5}{*}{ Married } \\
\hline Single & 4 & 10.0 & \\
\hline Widowed & 6 & 15.0 & \\
\hline Divorced & 2 & 5.0 & \\
\hline \multicolumn{3}{|l|}{ Educational Level } & \\
\hline No formal School & 8 & 20.0 & \multirow{5}{*}{ Secondary } \\
\hline Primary school & 11 & 27.5 & \\
\hline Secondary School & 17 & 42.5 & \\
\hline Tertiary School & 6 & 15.0 & \\
\hline \multicolumn{3}{|c|}{ Household size (persons) } & \\
\hline $1-5$ & 6 & 15.0 & \multirow{4}{*}{10 persons } \\
\hline $6-9$ & 11 & 27.5 & \\
\hline $10-13$ & 19 & 47.5 & \\
\hline & 4 & 10 & \\
\hline
\end{tabular}

Source: Field Data.

The study clearly indicates that's $65.0 \%$ and $35.0 \%$ respondents engaged in full-time and part-time fish selling business respectively fish sellers took fish business as their major occupation in the area as shown in Table 2. In a similar report, (9) stressed that consumers rely on availability of fish in appropriate, place, time and affordable cost. This is mostly achieved by full time fish sellers and not part time fish sellers.

Table 2 - Fish Sellers Business Status

\begin{tabular}{llllll}
\hline Status & Oleh & Aviara & Uzere & Irri & Entire \\
\hline Full time Business & $9(202 \%)$ & $6(15.0 \%)$ & $5(12.5 \%)$ & $7(17.5 \%)$ & $26(65 . \%)$ \\
Part Time Business & $2(5.0 \%)$ & $4(10.0 \%)$ & $5(12.5 \%)$ & $3(7.5 \%)$ & $14(35.0 \%)$ \\
Mode & & & & Full time business \\
\hline
\end{tabular}

Source: Field Data.

Marketing experience of fish sellers were on the range of $7-12$ years $(52.5 \%)$ with an average of experience of 9years 6months. Respondents with arrange of 1-6years were $22.5 \%$ as shown in the Table 3.This shows that those with higher experience engaged more in fish marketing for more marketing advantages. These findings agreed with Nworu (14) that experience as direct effects on efficiency and profit.

Table 3 - Marketing Experience of Fish Sellers

\begin{tabular}{llllll}
\hline Experience (years) & Oleh & Aviara & Uzere & Irri & Entire \\
\hline $1-6$ & $2(50.0 \%)$ & $3(7.5 \%)$ & $2(5.0 \%)$ & $2(5.0 \%)$ & $9(22.5 \%)$ \\
$7-12$ & $5(12.5 \%)$ & $4(10.0 \%)$ & $6(15.0 \%)$ & $6(15.0 \%)$ & $21(52.5 \%)$ \\
$13-18$ & $3(7.5 \%)$ & $3(7.5 \%)$ & $2(5.0 \%)$ & $2(5.0 \%)$ & 9 years 6 months \\
Mean & & & & & 9 \\
\hline
\end{tabular}

Source: Field Data. 
The results in Table 4 showed that selling price varies between $\$ 700$ and $\$ 740$ with an average selling price of $\$ 720$. The revenue average gotten from the sales of fish was $\$ 273$ 600 in the area. The selling price varies from one market to another depending on the market price ability. Higher selling prices attract greater profitability. (22) observed that the more the business opportunities in sales, the better the business profits.

Table 4 - Fish Sellers Revenue

\begin{tabular}{llllll}
\hline Items & Oleh & Aviara & Uzere & Irri & Entire Area \\
\hline Quantity Sold $(\mathrm{kg})$ & 380 & 380 & 380 & 380 & 1520 \\
Selling Price $(\mathrm{n})$ & 740 & 710 & 700 & 730 & 2880 \\
Total revenue & 281,200 & 269,800 & 266,000 & 277,400 & $1,094,400$ \\
Mean & & & & & $\mathrm{N} 273,600$ \\
\hline
\end{tabular}

Source: Field Data.

Cost of purchase, transportation and handling, preservation and miscellaneous were classified as total variable cost amounting to $\$ 189,320$ while the fixed cost such as store rent, tools ( basin, Cutlass, tables and others) and preservation materials such as charcoal, ice blocks oval/dryer and drying stands amounting to $\$ 22,025$ as shown in Table 5 this clearly revealed that total variable cost of fish sellers were more than the fixed cost. The increase cost of transportation and labour in fish marketing resulted from poor transportation network in the rural areas of Nigeria (3).

Table 5 - Fish Sellers Expedition (Total Cost)

\begin{tabular}{|c|c|c|c|c|c|}
\hline Cost & Oleh & Aviara & Uzere & Irri & Entire Area \\
\hline \multicolumn{6}{|l|}{ a. TVC } \\
\hline Quantity Purchased (kg) & 380 & 380 & 380 & 380 & 1520 \\
\hline Buying Price $(\AA)$ & 470 & 435 & 440 & 465 & 1,810 \\
\hline Total Cost of Purchase & 178,600 & 165,300 & 167,200 & 176,700 & 687,800 \\
\hline Transportation Cost (N) & 15,000 & 11,000 & 9,500 & 13,500 & 49,000 \\
\hline Preservation/Handling Cost & 4,500 & 2,000 & 2,500 & 4,000 & 13,000 \\
\hline Miscellaneous Cost $(\mathbb{A})$ & 2,300 & 1,200 & 1,900 & 2,100 & 7,500 \\
\hline Total Variable Cost (TVC) & 200,400 & & 181,100 & 196,300 & 757,300 \\
\hline $\begin{array}{l}\text { Mean TVC } \\
\text { b. TVC }\end{array}$ & & & & & 189,320 \\
\hline \multicolumn{6}{|l|}{ Selling tools } \\
\hline Store Rent & 6,200 & 6,100 & 6,300 & 6,000 & 24,600 \\
\hline Preservation materials & 11,000 & 7,000 & 8,500 & 10,000 & 36,500 \\
\hline Total fixed cost (TFC) & 7,500 & 6,000 & 6,500 & 7,000 & 27,000 \\
\hline Mean TFC N & 24,700 & 19,100 & 21,300 & 23,000 & 88,100 \\
\hline $\mathrm{TC}=\mathrm{TVC}+\mathrm{TFC}$ & $189320+22,025$ & & & & 211,345 \\
\hline
\end{tabular}

Source: Field Data.

Table 6 - Profitability of fish marketing

\begin{tabular}{|c|c|c|}
\hline \multicolumn{2}{|l|}{ Item } & \multirow{2}{*}{$\begin{array}{l}\text { Entire Area } \\
273,600\end{array}$} \\
\hline Total Revenue $(\mathrm{N})$ & & \\
\hline Total Variable Cost $(\mathbb{A})$ & & 189,230 \\
\hline Total Fixed Cost (N) & & 22,025 \\
\hline Total Cost & & 211,345 \\
\hline \multicolumn{3}{|l|}{$\mathrm{Gm}_{\mathrm{fs}}=\mathrm{R}_{\mathrm{fs}}-\mathrm{TVC}_{\mathrm{fs}}$} \\
\hline \multirow{2}{*}{$\begin{array}{l}\text { Gross Margin }\left(\mathrm{Gm}_{\mathrm{fs}}\right) \\
\text { Gross Margin }\end{array}$} & $=$ & $273,600-189,320$ \\
\hline & $=$ & N 84,280 \\
\hline $\mathrm{NR}_{\mathrm{fs}}$ & $=$ & $\mathrm{GM}_{\mathrm{fs}}-\mathrm{TFC}_{\mathrm{fs}}$ \\
\hline Net Returns & $=$ & N 62,255 \\
\hline \multirow[t]{4}{*}{$\mathrm{BCR}_{\mathrm{fs}}$} & $=$ & $\mathrm{TR}_{\mathrm{fs}}$ \\
\hline & $=$ & $\mathrm{TC}_{\mathrm{fs}}$ \\
\hline & $=$ & 273,600 \\
\hline & $=$ & 211,345 \\
\hline Benefit Cost Ratio & $=$ & 1.30 \\
\hline
\end{tabular}

Source: Field Data. 
Gross margin of fish marking was $\$ 84,280$ and the net returns was $\$ 62,255$ showing that there is profit in fish selling in the area. This is in line with the findings of federal department of fisheries (2007) that "Fish farming play a pivotal role in boosting human protein and major sources of income to the farmer" Benefit cost ratio of 1.30 reveals that each naira ploughed into the marketing business $30 \mathrm{k}$ was realized also indicating profit from the business as shown in Table 6 . This is in collaboration with the findings of (7) that when the margin difference between the total revenue and total cost is high it will result to maximum or greater profit. (22) further reported that efficiency of marketing of fresh fish could be high in adoption of fish marketing technology which is one of the biggest determinant of fish business as cost greatly affect income.

\section{CONCLUSION}

The results indicated that young people that were mostly married engage in fish selling business, women participated more than men in Fish marketing and were not educated most fish sellers where on full-time basis as their major occupation with average marketing experience of 9 years 6 months the selling price of the fish varies between $\$ 700$ and $\$ 740$ revealing that there is no standard price system. The revenue derived from Fish marketing

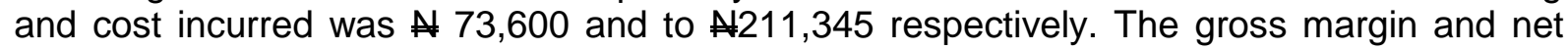
return of fish marketing was $\$ 84,280$ and $\$ 62,255$ respectively, this indicated that there was profit in business. Benefit cost ratio of 1.30 revealed that everyone naira ploughed into the fish marketing business thirty thousand naira was realized indicating profit in the business. The study recommends that marketing training programs should be carried out by NGO and government for acquisition of marketing skills further recommends a uniform price should be fixed by government especially the marketing boards.

\section{REFERENCES}

1. Abah, D. D. Akinayiba,B and Simon, E (2013).Economic of Fish Marketing Lafia Local Government Area of Nasarawa State, Nigeria. Journal of Production Agriculture and Technology 12(2):54-62.

2. Abolagba, O. J. and Nuntah, J. N (2011). Survey on cured fish processing, packaging, distribution and marketing in Edo and Delta States. International Research of Biotechnology 2(5).

3. Adeleke, M. L. N. and Afolabi, J. A. (2013). Appraisal of Fresh Fish Marketing in Ondo State, Nigeria FET Tanzanian Proceedings.

4. Akinbile, I.A and Alabi,O.F( 2010).Use of ICTs Among Fish Farmers of Oyo state, Journal of Agricultural Extension 14(1): 25-36.

5. Aphunu, A. and Agwu, A. (2014). Adoption of improved aquaculture management practices by clustered fish farmers in Delta State. Journal of Agricultural Extension, 18(2): $55-66$.

6. Atanda, A.N (2007). Freshwater Fish seed resources in Nigeria, PP 361-380.In M. C. Bondad Reantaso (Ed).Assessment of freshwater fish seed resources for sustainable aqua culture.

7. Debertin, D.L. (2012). Agricultural Production Economics (2 ${ }^{\text {nd }}$ ed). Macmillan Publishing Company, NJ, USA, Retrieved from http://www.knowledge.uky.edu/agecon_textbooks/1.

8. Federal Ministry of Agriculture and Rural Development (FMARD) (2016. The Agriculture Promotion Policy (2016-2020). Building on the successes of the ATA, closing key Gaps. Policy and Strategy Document.

9. FAO (2000).Marketing of fish. http://www.fao.org/3/y2876e0i.htm.

10. Federal Department of Fisheries (2005). Report of Presidential Committee fisheries and aquaculture Development volume one .Consolidated Report. Federal Department of Fisheries. Federal ministry of Agriculture and Rural Development, September 2005.

11. Food and Agricultural Organization (2004). Fisheries Technical Paper NO501, Rome FAO 628p. 
12. Gritinger J. P. (1994). Economic Analysis of Agricultural Projects. The John Hopkins University Press Baltimore.

13. Kotter, J. P. (2010). Marketing Management, 11th Edition, Prentice Hall Inc, New Jersey.

14. Nworu, J. C (2004). Rural credit-market and arable crop production in Imo State, Nigeria. Unpublished Ph.D Dissertation, Faculty of Agriculture Michael Okpara University of Agriculture Umudike Nigeria.

15. Nwuba, L. A and Onuoha, E. (2006)."Fish Farming in the Tropics; A Functional Approach Maxiprints, Awka, Nigeria.

16. Offor, E. I. and Nelson, F. A. (2005)."Marketing Efficiency of Poultry Egg in Umuahia South Local Government Area of Abia State, Nigeria. International journal of Applied Research and Technology 4(6): 3-7.

17. Okeke D. C. and Emaziye, P. O. (2017)."Technical Efficiency of smallholder cassava production in Anambra State, Nigeria: A Cobb-Douglas Stochastic Frontier production approach, The Nigerian Agricultural Journal 48(1): 66-71.

18. Olukunle, O. T. (2017). Profitability Analysis of Small Scale Fishery Enterprise in Nigeria. Journal of Agricultural Science 9(3):107 -115.

19. Ovharhe, O. J. (2016). Aquaculture Technologies Adoption by Fadama III Aquaculture Farmers in Niger Delta. Journal of Northeast Agricultural University23 (4): 78 - 81.

20. Ovharhe, O. J. (2019). Agricultural Project Design and Implementation in Nigeria: Review Models. Taraba Journal of Agricultural Research, 7(2): $1-7$.

21. Shimang, G.N. (2010). Fisheries Development in Nigeria, problems and prospects. A presentation by the Federal Director of Fisheries in the Federal Ministry of Agriculture and Rural Development on Homestead fish farming training in the Federal Ministry of Agriculture and Rural Development, Abuja, Nigeria.

22. 22 Ugwumba, C.O; Okoh, R.N; Uzuegbunam, C.O (2011). Market structure of live catfish in Anambra State, Nigeria. Journal of Agriculture and Social Sciences, Pakistan 5(1) pp 123-133.

23. Washington State Department of Health (WSDH) (2015). Health benefits of fish. http://www.doh.wa.gov/communityandenvironmental/fof/fish/healthbenefits, 2015. 